\title{
QUANTITY INDICATORS AS A MEASURE OF CREDIT MARKET INTEGRATION IN THE VISEGRAD COUNTRIES ${ }^{1}$
}

\author{
Pavla Vodová
}

Klíčová slova:

integrace úvěrových trhů, kvantitativní indikátory, země Visegrádské čtyřky

\section{Key words:}

credit market integration, quantity indicators, the Visegrad countries

\begin{abstract}
Abstrakt
Cílem článku je pomocí kvantitativních indikátorů ohodnotit, do jaké míry jsou úvěrové trhy v zemích Visegrádské čtyřky integrovány s úvěrovými trhy v zemích eurozóny. Uloha poboček zahraničních úvěrových institucí a podíl přeshraničních úvěrů ukazují, že integrace úvěrových trhů v zemích Visegrádské čtyřky roste. Proces integrace však byl zpomalen $\mathrm{v}$ důsledku finanční krize. Zejména $\mathrm{v}$ době krize jsou vysoce důležité informace o bonitě protistran. Protože banky mají přesnější informace o domácích subjektech, preferují poskytování úvěrů domácím dlužníkům.
\end{abstract}

\begin{abstract}
The aim of this paper is to assess with quantity indicators the extent to which credit markets in the Visegrad countries are integrated with euro zone countries. According to the role of foreign branches of credit institutions and the share of cross-border loans, integration of credit markets in the Visegrad countries is increasing. However, financial crisis has slowed the integration a bit. Especially during the crisis, information about creditworthiness of counterparties is highly important. Banks prefer to provide loans to domestic borrowers because better information is available about domestic counterparties.
\end{abstract}

\section{Introduction}

In light of the enlarging of European Union and the future entry of some countries in the euro area it has become increasingly important to follow the development in various segments of financial markets. Financial integration could enhance the effectiveness of the single monetary policy. A well integrated financial system increases the efficiency of an economy by reducing the cost of capital and improving the allocation of financial resources. The importance of an assessment of the degree of financial integration is therefore stressed by both central banks and academic institutions.

Measuring of credit market integration is quite complicated. It is possible to use method based on price indicators (as e.g. in Adam et al., 2002; Babetskii et al., 2007; Cabral et al., 2002; ECB, 2008; Komárková et al., 2008; Pungulescu, 2002 or Vodová, 2010b), quantity indicators (as e.g. in Adam et al., 2002; Baele et al., 2004 or Cabral et al., 2002) or news-based indicators (Baele et al., 2004; Babecky et al., 2009; Baltzer et al., 2008; Čermák, 2006 or Vodová, 2010c).

1 This paper was prepared with financial support of Czech Science Foundation - Project GAČR 402/08/0067

„Financial Integration of the EU New Member States with Eurozone“. 
The aim of this paper is to assess with quantity indicators the extent to which credit markets in the Visegrad countries are integrated with euro zone countries. The analysis is based on annual data about market penetration of foreign banks and home bias for the period from 2005 to 2009. The data were provided by European Central Bank (ECB), Bank for International Settlements (BIS), Deutsche Bundesbank (DBB) and supervisory authorities in the Visegrad countries: Česká národní banka (CNB), Národná banka Slovenska (NBS), Komisja nadzoru finansowego (KNF) and Pénzügyi Szervezetek Állami Felügyelete (PSZAF).

The paper is structured as follows. First section defines credit market integration and methods how to measure it. Second section focuses on quantity indicators. Last section analyzes the integration of credit markets in the Visegrad countries with euro zone countries with selected quantity indicators.

\section{Credit market integration and its measuring}

European Central Bank (2008) considers the market for a given set of financial instruments or services to be fully integrated, when all potential participants in such market:

- are subject to a single set of rules when deciding to buy or sell those financial instruments of services;

- have equal access to this set of financial instruments or services;

- and are treated equally when they operate in the market.

Adam et al. (2002) define financial markets as integrated when the law of one price holds. This states that assets generating identical cash flows command the same return, regardless of the domicile of the issuer and of the asset holder. Otherwise, the arbitrage opportunity exists and it should adjust prices to same level.

Credit markets are integrated when terms of credits (both financial and non-financial) are not influenced by geographical location of the bank.

The key to an accurately measured integration is to find assets, which have the same level of risk and generate identical cash flows. Then it is possible to choose which method to use. Essentially three methods prevail:

- method based on price indicators, which refer to the definition of integration, based on law of one price - see for example Adam et al. (2002), Babietskii et al. (2007), Cabral et al. (2002), ECB (2008), Komárková et al. (2008), Pungulescu (2002) or Vodová (2010a, b);

- method based on quantity indicators - this method is described in next section;

- method based on indicators of new information, which are designed to distinguish the information effects from other frictions or barriers - see for example Baele et al. (2004), Babecky et al. (2009), Baltzer et al. (2008), Čermák (2006) or Vodová (2010a, c).

\section{Quantity indicators}

Cabral et al. (2002) shows that many financial products and services are heterogeneous or different quality or even tailored to the needs of individual clients. Hence, the validity of the law of one price would be very difficult to establish, as the price signals are obscure. For these 
reasons, it is useful to evaluate not only price indicators but also quantity-based indicators, which can be interpreted as weaker, but still valuable, indicators of integration in the light of portfolio theory (e.g. allocation of investments across the single market area).

Quantity indicators are statistical data which should quantify determinants of demand and supply of investment opportunities and capture the importance and size of financial connections between countries. In general for the banking sector integration, quantity indicators involve market penetration of foreign banks and home bias.

Market penetration of foreign banks should increase in more integrated markets. Foreign banks can serve domestic customers directly by cross-border lending without establishing branches in the foreign country, by acquiring domestic banks or creating domestic branches. It is possible to measure market penetration of foreign banks by:

- the share of assets held by foreign banks;

- the share of foreign banks in the total number of banks operating in a country.

Baele et al. (2004) define home bias as the fact that agents tend to invest more in domestic assets even though risk is share more effectively if foreign assets are held. The existence of home bias is a sign that financial integration is still not complete. When markets are perfectly integrated, the home bias should disappear. Adam et al. (2002) recommend these indicators of home bias:

- the share of foreign assets held by the national banking sector in a country benchmarked with those shares that banks would hold if they lent to all countries in proportion to the relative size of the corresponding credit market;

- the aggregate foreign asset index for the domestic banking sector of the whole Euro area, constructed by weighting the shares of foreign assets in each country's banking sector by the relative size of domestic credit markets;

- the share of foreign liabilities held by the national banking sector in a country, which should be benchmark with those shares that banks would hold if they relied on national financing sources in proportion to the size of the domestic markets for deposits, money market instruments and bonds;

- the aggregate foreign liability index for the domestic banking sector of the whole Euro area, constructed by weighting the shares of foreign liabilities in each country's banking sector by the relative size of domestic markets for deposits, money market instruments and bonds.

These indirect, quantity-based indicators of integration need to be interpreted prudently. For instance, an entry by a foreign bank via the purchase of an existing local bank does not necessarily imply integration, as the acquired bank may continue to operate as before in the local market, and the pricing conditions will not necessarily converge across local markets.

This paper focuses on credit markets rather than on the whole banking sector. Moreover, comparing with price indicators and news-based indicators, the lack of needed data makes the application of quantity indicators very difficult. For these reasons, we will apply the following quantity indicators to measure the credit market integration. Market penetration of foreign credit institutions will be measured by:

- the share of foreign branches in the total number of credit institutions operating in a country;

- the share of loans provided by branches of foreign credit institutions in total volume of loans provided in a country. 
Home bias will be captured by:

- the share of cross-border loans of banks to non-bank sector in total volume of loans provided in a country;

- the share of interbank cross-border loans in total volume of loans provided in a country.

For all these indicators, greater values of the indicator suggest that it is easier for foreigners to access a regional credit market. Therefore it is a sign of growing integration of credit markets.

\section{Integration of credit markets in the Visegrad countries with euro zone countries}

The extent of market penetration of foreign credit institutions in the Visegrad countries is shown in Tables 1 and 2.

Table 1: Credit institutions in the Visegrad countries and in euro area

\begin{tabular}{|c|c|c|c|c|c|}
\hline & 2005 & 2006 & 2007 & 2008 & 2009 \\
\hline \multicolumn{6}{|c|}{ Czech Republic } \\
\hline domestic credit institutions & 44 & 44 & 42 & 38 & 38 \\
\hline foreign branches & 12 & 13 & 14 & 20 & 18 \\
\hline branches of euro area-based institutions & 10 & 11 & 11 & 12 & 15 \\
\hline branches of non-euro area-based instit. & 2 & 2 & 3 & 8 & 3 \\
\hline share of foreign branches & $21.4 \%$ & $22.8 \%$ & $25.0 \%$ & $34.5 \%$ & $32.1 \%$ \\
\hline \multicolumn{6}{|c|}{ Slovakia } \\
\hline domestic credit institutions & 18 & 17 & 16 & 17 & 15 \\
\hline foreign branches & 5 & 7 & 5 & 9 & 11 \\
\hline branches of euro area-based institutions & 3 & 4 & 5 & 5 & 7 \\
\hline branches of non-euro area-based instit. & 2 & 3 & 0 & 4 & 4 \\
\hline share of foreign bra & $21.7 \%$ & $29.2 \%$ & $23.8 \%$ & $34.6 \%$ & $42.3 \%$ \\
\hline \multicolumn{6}{|c|}{ Poland } \\
\hline domestic credit inst & 724 & 711 & 705 & 694 & 691 \\
\hline foreign branches & 6 & 12 & 13 & 18 & 19 \\
\hline branches of euro area-based institutions & 4 & 7 & 8 & 14 & 15 \\
\hline branches of non-euro area-based instit. & 2 & 5 & 5 & 4 & 4 \\
\hline share of foreign branches & $0.8 \%$ & $1.7 \%$ & $1.8 \%$ & $2.5 \%$ & $2.7 \%$ \\
\hline \multicolumn{6}{|c|}{ Hungary } \\
\hline domestic credit ins & 214 & 208 & 201 & 199 & 180 \\
\hline foreign branches & 0 & 4 & 5 & 5 & 10 \\
\hline branches of euro a & 0 & 4 & 0 & 5 & 10 \\
\hline branches of non-euro area-based instit. & 0 & 0 & 5 & 0 & 0 \\
\hline share of foreign branches & $0.0 \%$ & $1.9 \%$ & $2.4 \%$ & $2.5 \%$ & $5.3 \%$ \\
\hline \multicolumn{6}{|c|}{ Euro area } \\
\hline domestic credit institutions & 7941 & 5590 & 5601 & 6097 & 7520 \\
\hline foreign branches & 675 & 540 & 588 & 641 & 840 \\
\hline branches of euro area-based institutions & 436 & 368 & 400 & 422 & 559 \\
\hline branches of non-euro area-based instit. & 239 & 172 & 188 & 219 & 281 \\
\hline share of foreign branches & $7.8 \%$ & $8.8 \%$ & $9.5 \%$ & $9.5 \%$ & $10.1 \%$ \\
\hline
\end{tabular}

Source: ECB Statistical Data Warehouse, own calculations

The share of foreign branches in the total number of credit institutions operating in a country 
has substantially grown in all analyzed countries and in euro area as well (Table 1). Most branches of foreign credit institutions are legally incorporated in euro area. Branches from outside euro area are much less important.

Although the share of foreign branches is growing in all countries, their importance significantly differs among countries. The share of foreign branches has reached a third of total number of credit institutions in the Czech Republic and almost half in Slovakia. In contrast, their shares in Poland and Hungary are very low. The reason can be found in different credit market structure. As it can be seen from the Table 1, the number of domestic credit institutions is substantially higher in Poland and Hungary because of important role of cooperative banks in Poland and cooperative credit institutions in Hungary.

As it can be seen in Table 2, the share of loans provided by branches of foreign credit institutions in total volume of loans provided in a country does not correspond with the share of foreign branches in total number of credit institutions - the market share of foreign branches on loans is significantly lower for the Czech Republic and Hungary and substantially higher for Poland. This can be caused by higher credit market concentration and lower lending activity of foreign branches. Branches of foreign banks often concentrate especially on corporate finance services, trading activities and private banking (Baele et al., 2004).

Table 2: Share of loans provided by branches of foreign credit institutions in selected Visegrad countries $^{2}$

\begin{tabular}{|l|l|l|r|r|c|}
\hline & 2005 & 2006 & \multicolumn{1}{|c|}{2007} & \multicolumn{1}{|c|}{2008} & \multicolumn{1}{|c|}{2009} \\
\hline Czech Republic & $7.31 \%$ & $8.02 \%$ & $10.70 \%$ & $10.66 \%$ & $8.65 \%$ \\
\hline Poland & $0.74 \%$ & $2.52 \%$ & $3.63 \%$ & $5.03 \%$ & $5.40 \%$ \\
\hline Hungary & $0.06 \%$ & $0.51 \%$ & $0.39 \%$ & $0.67 \%$ & $1.71 \%$ \\
\hline
\end{tabular}

Source: Own calculations based on data of CNB, KNF and PSZAF

The values of the share of cross-border loans of banks to non-bank sector in total volume of provided loans in a country are surprising (Table 3). Banks in all Visegrad countries, mainly in Hungary, provide more cross-border (i.e. external) loans than average bank in euro zone. However, average values can be sometimes very tricky. According to the European Parliament (2007), the extent of cross-border lending to non-bank sector varies in the euro area from $2.8 \%$ of lending in Greece to $76.5 \%$ of lending in Luxemburg at the end of 2006.

Table 3: The share of cross-border loans of banks to non-bank sector in the Visegrad countries and in euro area

\begin{tabular}{|l|r|r|r|r|c|}
\hline & \multicolumn{1}{|c|}{2005} & 2006 & 2007 & 2008 & 2009 \\
\hline Czech Republic & $20.24 \%$ & $20.35 \%$ & $17.96 \%$ & $17.97 \%$ & $17.21 \%$ \\
\hline Slovakia & $12.23 \%$ & $12.01 \%$ & $15.05 \%$ & $16.35 \%$ & $16.95 \%$ \\
\hline Poland & $16.94 \%$ & $17.73 \%$ & $14.86 \%$ & $14.64 \%$ & $14.30 \%$ \\
\hline Hungary & $20.09 \%$ & $16.90 \%$ & $20.97 \%$ & $27.40 \%$ & $31.79 \%$ \\
\hline Euro area & $11.29 \%$ & $11.80 \%$ & $12.44 \%$ & $11.92 \%$ & $11.18 \%$ \\
\hline - with EU countries & $6.20 \%$ & $6.70 \%$ & $7.25 \%$ & $6.70 \%$ & $6.17 \%$ \\
\hline - with non-EU countries & $5.09 \%$ & $5.10 \%$ & $5.18 \%$ & $5.21 \%$ & $5.02 \%$ \\
\hline
\end{tabular}

Source: Own calculations based on data of BIS, CNB, DBB, KNF, NBS and PSZAF

\footnotetext{
${ }^{2}$ Data for Slovakia and euro zone were not available.
} 
The data in Table 3 also show that the share of cross-border loans decreased during the last one or two years (Slovakia and Hungary are exceptions). The reason can be found in reduced and more prudent lending activity of banks due to financial crisis. Banks have better information about creditworthiness of domestic borrowers. As stated in Baele et al. (2004), banks prefer to be close to their customers, especially in retail banking.

Table 4 shows the values of the share of interbank cross-border loans in total volume of loans provided in a country. Values are very similar to those for loans to non-bank sector. Hungarian and Polish interbank markets are nowadays most open to external loans. However, Czech and Slovak banks provide less cross-border interbank loans than average bank in euro zone.

Table 4: The share of interbank cross-border loans in the Visegrad countries and in euro area

\begin{tabular}{|l|r|r|r|r|r|}
\hline & \multicolumn{1}{|c|}{2005} & \multicolumn{1}{c|}{2006} & 2007 & 2008 & 2009 \\
\hline Czech Republic & $21.23 \%$ & $17.85 \%$ & $19.17 \%$ & $16.15 \%$ & $12.05 \%$ \\
\hline Slovakia & $30.71 \%$ & $16.94 \%$ & $26.82 \%$ & $26.79 \%$ & $16.19 \%$ \\
\hline Poland & $11.20 \%$ & $12.59 \%$ & $19.82 \%$ & $22.32 \%$ & $21.20 \%$ \\
\hline Hungary & $31.91 \%$ & $31.96 \%$ & $32.43 \%$ & $40.47 \%$ & $39.05 \%$ \\
\hline Euro area & $19.50 \%$ & $20.50 \%$ & $21.11 \%$ & $18.35 \%$ & $17.64 \%$ \\
\hline - with EU countries & $15.57 \%$ & $16.72 \%$ & $16.95 \%$ & $13.71 \%$ & $13.96 \%$ \\
\hline - with non-EU countries & $3.93 \%$ & $3.77 \%$ & $4.16 \%$ & $4.63 \%$ & $3.68 \%$ \\
\hline
\end{tabular}

Source: Own calculations based on data of BIS, CNB, DBB, KNF, NBS and PSZAF

One can see a gradual increase in cross-border interbank loans. As in case of loans to nonbank sectors, during the last two years the share of cross-border loans decreased. The reason is obvious: freezing up of the interbank market due to the financial crisis.

\section{Conclusion}

The aim of this paper was to assess with quantity indicators the extent to which credit markets in the Visegrad countries are integrated with euro zone countries.

Because of lack of needed data, we had to modify quantity indicators. We used two indicators of market penetration of foreign credit institutions (the share of foreign branches in the total number of credit institutions operating in a country and the share of loans provided by branches of foreign credit institutions in total volume of loans provided in a country) and two indicators of home bias (the share of cross-border loans of banks to non-bank sector in total volume of loans provided in a country and the share of interbank cross-border loans in total volume of loans provided in a country).

The share of foreign branches in the total number of credit institutions operating in a country has substantially grown in all analyzed countries and in euro area as well. Foreign branches are most important in Slovakia and in the Czech Republic. The market share of foreign branches on loans is significantly lower for the Czech Republic and Hungary and substantially higher for Poland.

Banks in all Visegrad countries, mainly in Hungary, provide more cross-border loans to nonbank sectors than average bank in euro zone. Hungarian and Polish interbank markets are nowadays most open to external loans. However, Czech and Slovak banks provide less crossborder interbank loans than average bank in euro zone. Both for cross-border loans to nonbank sector and cross-border interbank loans, their share have decreased due to financial crisis 
during the last two years.

One can conclude that according to quantity indicators, the integration of credit markets in the Visegrad countries is increasing. However, financial crisis has slowed the integration a bit. It is entirely logical consequence: especially during the crisis, information about creditworthiness of counterparties is highly important and banks still have much better information about creditworthiness of domestic counterparties (households, companies and financial institutions as well).

\section{References:}

[1] ADAM, K., JAPPELli, T., MENICHINI, A., PADUlA, M., PAGANO, M. Analyse, Compare and Apply Alternative Indicators and Monitoring Methodologies to Measure the Evolution of Capital Market Integration in the European Union. Palermo: University in Palermo, CSEF, 2002.

[2] BABECKY, J., FRAIT, J., KOMÁREK, L., KOMÁRKOVÁ, Z. Price- and News-based Measures of Financial Integration among New EU Member States and the Euro Area. London Metropolitan Business School, 2009.

[3] BABIETSKII, I., KOMÁREK, L., KOMÁRKOVÁ, Z. Financial Integration of Stock Markets among New EU Member States and the Euro Area. CNB Working Paper Series, No. 7, 2007.

[4] BAELE, L., FERRANDO, A., HÖRDAHL, P., KRYLOVA, E., MONNET, C. Measuring Financial Integration in the Euro Area. ECB Occasional Paper Series, No. 14, 2004.

[5] BALTZER, M., CAPPIELlO, L., DE SANTIS, R.A., MANGANELLI, S. Measuring Financial Integration in New EU Member States. ECB Occasional Paper Series, No. 81, 2008.

[6] CABRAL, I., DIERICK, F., VESALA, J. Banking Integration in the Euro Area. Frankfurt: European Central Bank, 2002.

[7] ČERMÁK, P. Integrace finančního trhu EU. Praha: Ministerstvo financí, 2006.

[8] ECB. Financial integration in Europe. Frankfurt: European Central Bank, 2008. ISSN 1830-7159.

[9] EUROPEAN PARLIAMENT. Broad Economic Analysis of the Impact of the Proposed Directive on Consumer Credit. Brusel: European Parliament, 2007.

[10]KOMÁRKOVÁ, Z., FRAIT, J., KOMÁREK, L. Integrace úvěrových trhů vybraných nových členských zemí Evropské unie s eurozónou. Ostrava: VŠB-TU, 2008.

[11]PUNGULESCU, C. Measuring Financial Market Integration: An Application for the East-European New Member States. Tilburg: Tilburg University, 2002.

[12] VODOVÁ, P. Credit Market Integration and its Measuring. In STAVÁREK, D., VODOVÁ, P. (ed.) Proceedings of the 12th International Conference on Finance and Banking. Karviná: SU OPF, 2010a, pp. 260 - 265. ISBN 978-80-7248-592-5.

[13] VODOVÁ, P. Markets of loans provided to households and their integration measured by price indicators. In Proceedings of the 28th International Conference on Mathematical Methods in Economics 2010. České Budějovice : University of South Bohemia, Faculty of Economics, 2010b, s. 664 - 669. ISBN 978-80-7394-218-2.

[14] VODOVÁ, P. News-based Indicators as a Measure of Credit Market Integration in the Visegrad Countries. In Řizení a modelování finančních rizik. Ostrava : VŠB - TU, 2010c, s. 446 - 452. ISBN 978-80-248-2306-5.

[15] http://www.bis.org

[16] http://www.bundesbank.de

[17]http://www.cnb.cz 
[18]http://sdw.ecb.europa.eu

[19] http://www.knf.gov.pl/index.html

[20] http://www.nbs.sk

[21] http://www.pszaf.hu

Classification JEL: F36, G15

Ing. Pavla Vodová, Ph.D.

Assistant Professor, Department of Finance

School of Business Administration in Karviná

Silesian University in Opava

Univerzitní nám. 1934/3

73340 Karviná

vodova@opf.slu.cz 